Primljen / Received: 18.4.2013. Ispravljen / Corrected: 19.8.2013.

Prihvaćen / Accepted: 12.9.2013.

Dostupno online / Available online: 10.10.2013.

\section{Application of temperature simulation for seepage inspection in earth-fill dams}

\section{Authors:

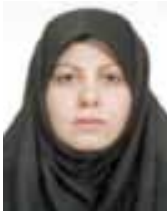 \\ Somayeh Yousefi, Ph.D. candidate Science and Research Branch \\ Islamic Azad University (IAU) \\ Tehran, Iran \\ yous1383@hotmail.com

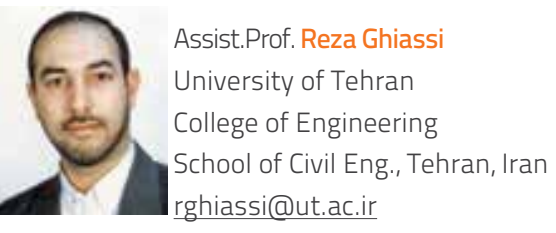

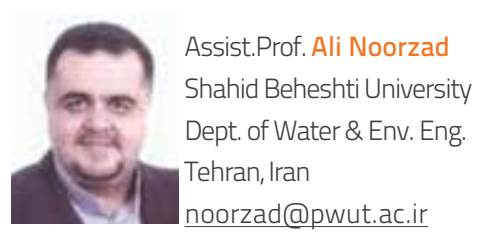

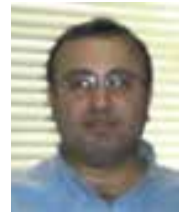

Assoc.Prof. Mohsen Ghaemian Sharif University of Technology Department of Civil Engineering

Tehran, Iran

ghaemian@sharif.edu

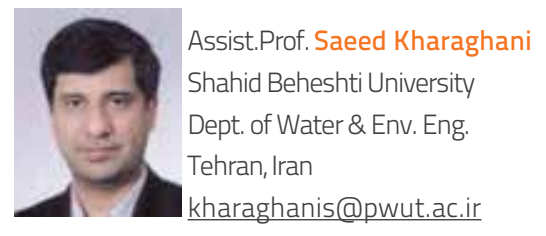

Scientific paper - preliminary report

Somayeh Yousefi, Reza Ghiassi, Ali Noorzad, Mohsen Ghaemian, Saeed Kharaghani

Application of temperature simulation for seepage inspection in earth-fill dams

The earth-fill dam leakage is studied in this paper by applying the seepage flow and thermal simulation. The mass balance and convection-diffusion equations are discretized based on the finite element method to solve the phenomena in saturated and unsaturated zones. The Shamil embankment dam is used for verification of the proposed model. Different conductivity cases are analyzed and compared against measured data. Results show that investigation of temperature variations can magnify the effect of leakage more clearly than the inspection of seepage piezometric levels.

Key words:

earthen dam, seepage flow, thermal simulation, piping, finite element analysis

Znanstveni rad - prethodno priopćenje

Somayeh Yousefi, Reza Ghiassi, Ali Noorzad, Mohsen Ghaemian, Saeed Kharaghani

Primjena postupka simuliranja temperature u kontroli procjedivanja kod nasutih brana

U ovom se radu razmatra procjeđivanje zemljane brane simuliranjem procjednog toka i toplinskih parametara. Jednadžbe za izjednačavanje masa i za konvekciju-difuziju diskretizirane su pomoću metode konačnih elemenata radi rješavanja tih pojava u zasićenim i nezasićenim zonama. Predloženi model je provjeren na primjeru zemljane brane Shamil. Analizirani su primjeri materijala raznih karakteristika provodljivosti te je izvršena usporedba s mjernim podacima. Rezultati pokazuju da se ispitivanjem temperaturnih varijacija pojava procjeđivanja može jasnije sagledati nego kod piezometarske kontrole procjedivanja.

Ključne riječi:

zemljana brana, procjeđivanje, toplinska simulacija, stvaranje erozijskih kanala, metoda konačnih elemenata

Wissenschaftliche Arbeit - Vorherige Mitteilung

Somayeh Yousefi, Reza Ghiassi, Ali Noorzad, Mohsen Ghaemian, Saeed Kharaghani

Einsatz von Temperatursimulierung beim Inspizieren der Versickerung von Erddämmen

Die Hauptursache der Beschädigung von Erddämmen sind unvorhergesehene Versickerungen. Es ist wichtig, die Quantität des Sickerstroms zu bestimmen und die Bedingungen möglicher Dammbrüche vorherzusehen. Der Bruch von Erddämmen ist in diesem Artikel durch den Einsatz numerischer Simulierungen von Versickerung und Temperatur bearbeitet. Temperaturänderungen im Dammkörper können simuliert werden, um die Wassergeschwindigkeit in den Erdschichten zu ermitteln. Während des Flusses durch den Dammkörper besitzt der Sickerstrom alle physischen Eigenschaften des Stauwassers, einschließlich der entsprechenden Temperatur.

Schlüsselwörter:

Erddamm, Sickerstrom, thermische Simulierung, Leitung, Finite-Elemente-Analyse 


\section{Introduction}

The quantity of seepage flow is often referred to as one of key parameters for evaluating dam safety. An earth-fill dam safety program usually includes surveillance systems to address seepage water control and leakage detection. Different instruments are installed in the dam body in order to collect seepage flow parameters, measure seepage rates, and detect possible presence of transported materials. Generally, the spatial distribution of these instruments is often not refined enough to detect small and local seepage characteristics. This may be one of the main reasons why most internal erosion incidents have been detected by visual inspections, rather than by monitoring systems [1]. Consequently, there is a need for new and improved seepage detection and monitoring techniques.

It is generally easy to measure temperature data, and this measurement can provide useful information about the presence of anomalous flows being transported from different regions of the dam [2]. Temperature measurements for the detection of seepage in dams were first conducted in Germany in the late 1950's [3]. Extensive research was also performed, especially in Germany and Sweden, for three decades, starting in 1950's [4].

The seepage monitoring method is based on seasonal temperature variations that occur in all surface water (such as lakes, reservoirs and rivers), and so we also have a seasonal variation of the seepage water that passes through a dam. The magnitude of this seasonal temperature variation can be measured in the dam, and is correlated to the seepage flow through the dam. The basic approach was described by Kappelmayer in 1957 and by Johansson in 1991 [5]. When it is necessary to monitor the leakage over long periods and distances, the distributed temperature sensors, based on optical fibers, provide an efficient solution, as they are capable of providing a global view, as well as a detailed local view of the inspected site [6].

On various projects in Brazil, China and Jordan, the Distributed Fiber Optic Temperature (DFOT) measurement has proven to be a suitable tool for the highly sophisticated temperature monitoring in RCC and earthen dams as well [7]. As acceptable and accurate results have been achieved in seepage monitoring using the mentioned methods, this technology is now being recognized as the most effective way to detect seepage flow changes, with high sensitivity along the entire dam. This paper presents the application of seepage flow simulation and temperature transmission modelling for the purpose of evaluating the piping characteristics. The comparison of different cases of leakage can reveal the efficiency of application of both flow and thermal simulation for quantifying dam measured data.

\section{Flow and thermal processes in dams}

The temperature in an earth-fill dam is related to the air temperature and temperature of the upstream water reservoir. These temperatures vary seasonally and create temperature waves that propagate through the dam. Normally, the seepage flow is small in embankment dams and the seasonal temperature variation in the dam depends essentially on the air temperature at the surface. The influence of the air is however less than $1{ }^{\circ} \mathrm{C}$ for depths in the dam body that exceed $10 \mathrm{~m}$. At such depths, the influence of air is therefore negligible. At high seepage rates, the temperature variation of the water in the upstream reservoir completely determines the temperature inside the dam. The seasonal temperature variation in the dam is then directly proportional to the seepage rate. Basically, a constant temperature at the downstream of the dam core is a sign of small seepage, while large seasonal variations may be a sign of significant seepage. At a higher seepage flow, the temperature in the dam will be changed, and the seasonal variation will increase. This variation is dependent on seepage flow, the seasonal variation at the inflow boundary, and the distance from the boundary to the measuring point.

The thermohydraulic behaviour of an earth-fill dam is quite complex. It includes such basic thermal processes as heat conduction, advection and dispersion. The problem is further complicated by the variation in material properties of the dam, and the different conditions in the saturated and unsaturated parts of the dam. Certain general assumptions have to be made. The general problem can, however, be studied using coupled mass flow and energy transport models. The mass, energy and concentration equations can be applied to simulate the seepage flow and heat transport through porous media.

\subsection{Mass balance equation}

The mass conservation equation in a porous media can be expressed as:

$\frac{\partial\left(\rho_{f} n\right)}{\partial t}+\frac{\partial}{\partial x_{i}}\left(\rho_{f} q_{i}\right)=0$

where:

$\rho_{f}=$ density of fluid $\left[\mathrm{kg} / \mathrm{m}^{3}\right]$

$n$ = porosity coefficient

$x_{i}=$ distance

$q_{i}=$ leakage flow (Darcy flow), (m/s or $\mathrm{m}^{3} / \mathrm{s}$ or $\mathrm{m}^{2} / \mathrm{s}$ )

$t=$ time

A general form of the Darcy's law can be used to describes the velocity of seepage water:

$q_{i}=-\frac{k_{i j}}{\mu}\left(\frac{\partial p}{\partial x_{i}}+\rho_{f} g_{i}\right)$ 
where:

$k_{i j}=$ permeability

$\mu=$ dynamic viscosity

$p$ = pressure

$g_{i}=$ gravity

Hence, the equation of motion for the leakage water flow can be obtained by combining Eqs. (1) and (2), which results in

$\frac{\partial\left(\rho_{f} n\right)}{\partial t}+\frac{\partial}{\partial x_{i}}\left(k_{i j} \frac{\partial p}{\partial x_{i}}+\rho_{f} k_{i j} g_{j}\right)=0$

This equation, with initial and boundary conditions, describes the leakage water flow induced by the variation of pressure (or piezometric head), and by the variation of water density.

\subsection{Energy balance equation}

In an earth-fill dam, the energy flux consists of heat conduction in the solid phase and heat transportation in the liquid phase. Energy flux in the water (liquid phase) includes heat advection with the average leakage water flow, and dispersion due to variability in the leakage water flow velocities. The energy balance equation can be expressed in the form of general advection-dispersion equation, [8]:

$c_{0} \frac{\partial T}{\partial t}=\frac{\partial}{\partial x_{i}}\left(\lambda_{0} \frac{\partial T}{\partial x_{i}}-c_{w} T q_{i}-Q_{i}^{\text {disp }}\right)$

where:

$c_{0} \quad=$ volumetric heat capacity of soil [ $\left./ \mathrm{m}^{2} \mathrm{~K}\right]$

$c_{w}=$ volumetric heat capacity of water $\left[\mathrm{J} / \mathrm{m}^{2} \mathrm{~K}\right]$

$Q_{i}^{\text {disp }}=$ energy flux due to mechanical and thermal dispersion $\left[\mathrm{J} / \mathrm{m}^{2} \mathrm{~s}\right]$

$\mathrm{q}_{\mathrm{i}} \quad=$ leakage flow (Darcy flow), [m/s or $\mathrm{m}^{3} / \mathrm{s}$ or $\mathrm{m}^{2} / \mathrm{s}$ ]

$T \quad=$ temperature $\left[{ }^{\circ} \mathrm{C}\right]$

$$
\begin{array}{ll}
t & =\text { time }[\mathrm{s}] \\
x_{i} & =\text { coordinate } \\
\lambda_{0} & =\text { thermal conductivity of soil }
\end{array}
$$

Equation (4) describes the time variation of energy based on advection terms (related to leakage flux), diffusive terms (related to soil thermal conductivity) and dispersive terms (related to soil thermal dispersion).

\section{Case study}

In order to investigate the proposed model, the Shamil earthfill dam, located in the south of Iran, has been considered as the case study. The height of the dam is $32.2 \mathrm{~m}$, while the reservoir volume is $115 \mathrm{MCM}$. The total of eight different soil types were taken in order to simulate the base, core, shell, drainage, and filter of the Shamil Dam.

\subsection{Technical specifications}

The body of the Shamil Dam is an embankment with a slightly inclined central core made of fine clay. The dam core is supported with two filter layers on both upstream and downstream sides, and a drain layer at the downstream side. The dam crest width is $8 \mathrm{~m}$, and the length is $1200 \mathrm{~m}$. Over the past 1.5 years, the annual water level fluctuation in the reservoir amounted to

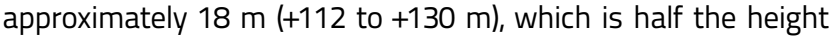
of the dam. The dam foundation material is conglomerate. A cutoff wall $11 \mathrm{~m}$ in height was constructed under the core. The dam body and its foundation materials consist of 8 different layers which are defined in the numerical model as: 1-core, 2-filter, 3-drain, 4-shell, 5-cutoff, 6-alluvium, 7-weathered-rock and 8-conglomerate, as shown in Figure 1. The coefficient of permeability is presented for each material layer in Table 1 [9].

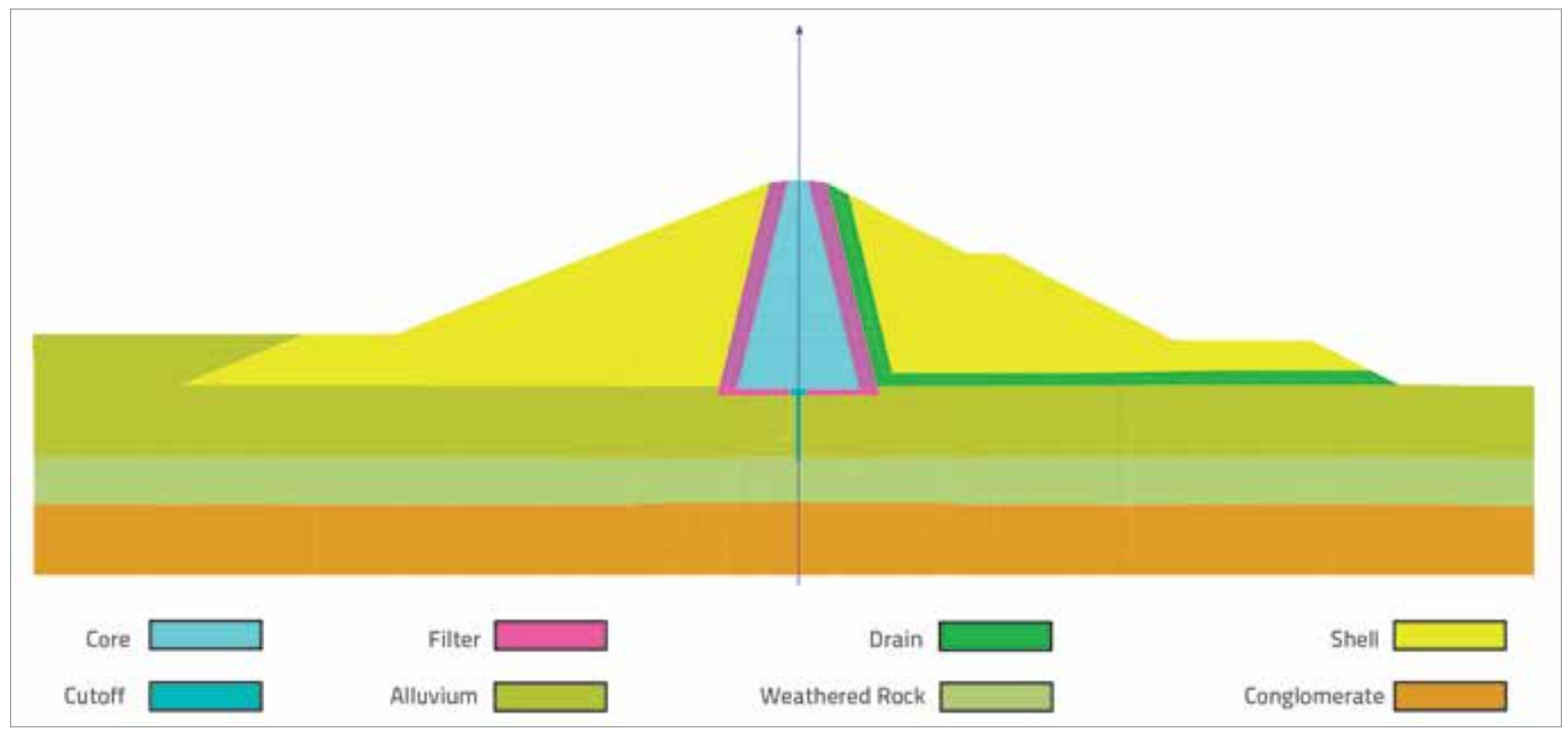

Figure 1. Different material layers in dam body and foundations 
Table 1: Technical specification of soil materials in Shamil dam

\begin{tabular}{|c|c|c|c|}
\hline Part & $\boldsymbol{k}[\mathrm{m} / \mathrm{s}]$ & Part & $\boldsymbol{k}[\mathrm{m} / \mathrm{s}]$ \\
\hline Core & $8,3 \times 10^{-9}$ & Filter & $2,5 \times 10^{-7}$ \\
\hline Alluvium & $2,3 \times 10^{-3}$ & Drain & $7 \times 10^{-5}$ \\
\hline Cutoff wall & $1 \times 10^{-7}$ & Shell & $2,3 \times 10^{-5}$ \\
\hline Conglomerate & $1 \times 10^{-5}$ & Weathered-rock & $1-10^{-5}$ \\
\hline
\end{tabular}

\subsection{Computational domain}

Based on river topography in the dam area, the total of 21 different cross sections were studied in the dam design. The instrumentation of the Shamil Dam was installed at sections number $10,14,19$, and 21 . The section number 14 is the largest section of the dam. It is located almost in the middle of the river and has been selected for seepage studies in this paper. At section 14, the bottom layer of foundations is about $76 \mathrm{~m}$, and the top layer of foundations is $110 \mathrm{~m}$, where the bottom of the core is constructed. Also, the dam crest is at $142.5 \mathrm{~m}$. By considering the dam cross-section, $203 \mathrm{~m}$ in length at the riverbed level, the total length of foundation is considered to be $250 \mathrm{~m}$.

The computational domain in the horizontal and vertical directions has been discretised into 56 and 48 elements, respectively. The total number of quadrilateral and triangular elements in the cross section is 1433 , and the total number of nodes is 1451 . The minimum dimension of elements is about $0.5 \times 0.5 \mathrm{~m}$ close to cutoff wall, and the maximum size of elements increases to $4 \times 7.5 \mathrm{~m}$ at the upstream side of dam foundations. (Figure 2).

\subsection{Boundary conditions}

Over the past several years, the Shamil Dam construction was finalized and the impounding has started. Before construction, riverbed at dam axis was $112 \mathrm{~m}$ in the first impoundment. Due to huge sedimentation, the bed level at the dam reservoir increased to $118 \mathrm{~m}$ and remained constant for about two years (during the studying period). In the past 1.5 years, the water level in dam reservoir mostly varied between 118 and 129 $\mathrm{m}$, as shown in Figure 3. These variations can be considered as upstream boundary conditions for an unsteady seepage simulation. Water temperature in the dam reservoir also varied from 19 to 35 degrees centigrade, as illustrated in Figure 3. The water passing through the dam body keeps its physical properties including the temperature. Unsteady boundary conditions have been applied for temperature simulation.

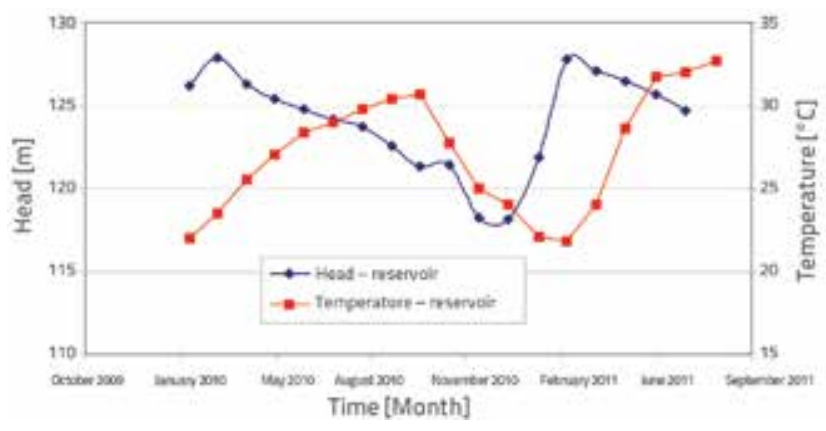

Figure 3. Variation of water level and temperature in the Shamil Dam reservoir

\section{Seepage analysis}

Relevant equations of flow and energy, described in chapter 2, were discretised based of the finite element method with triangular and quadrilateral elements. Discretised equations for saturated and unsaturated zones were solved for temporal boundary conditions. The water table in each time step can be established from the percentage of saturation of the elements.

Recorded data on the water level and water temperature in dam reservoir, shown in Figure 3, were applied as the upstream boundary condition for the numerical modelling of seepage and temperature. At the downstream face, the water level measured at the riverbed amounted to $112 \mathrm{~m}$. Results of numerical simulation of seepage flow based on design data

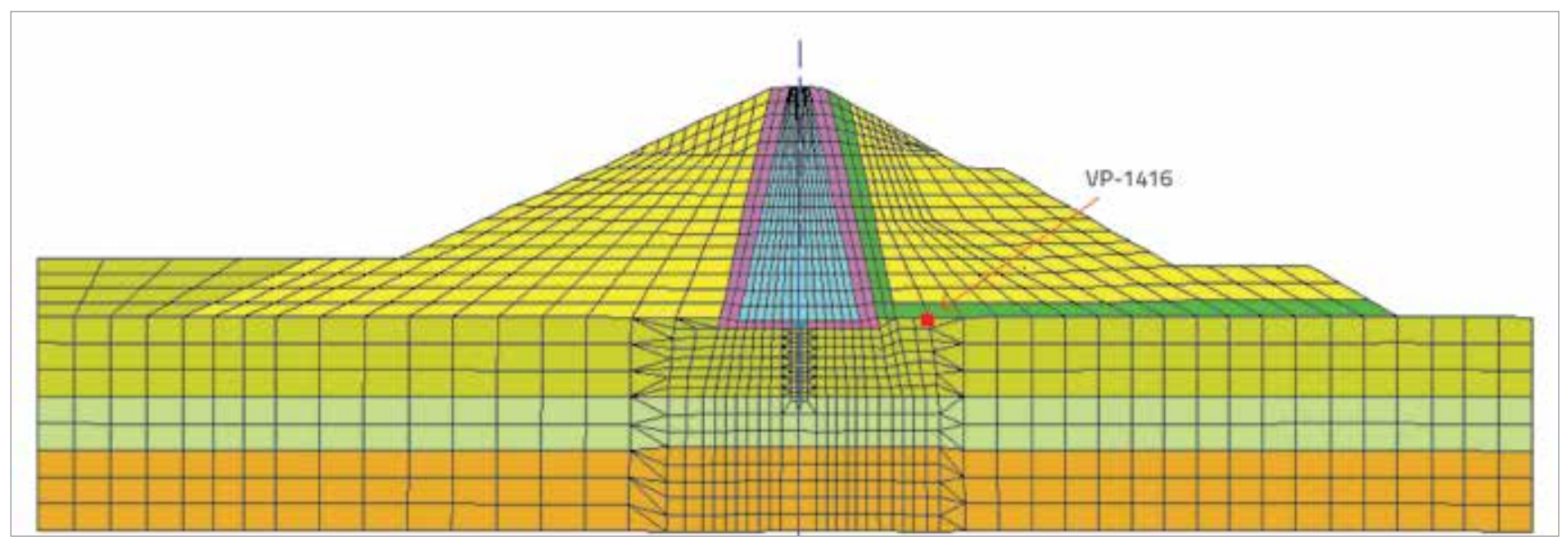

Figure 2. Computational domain of the Shamil Dam (with the location of piezometer 1416) 


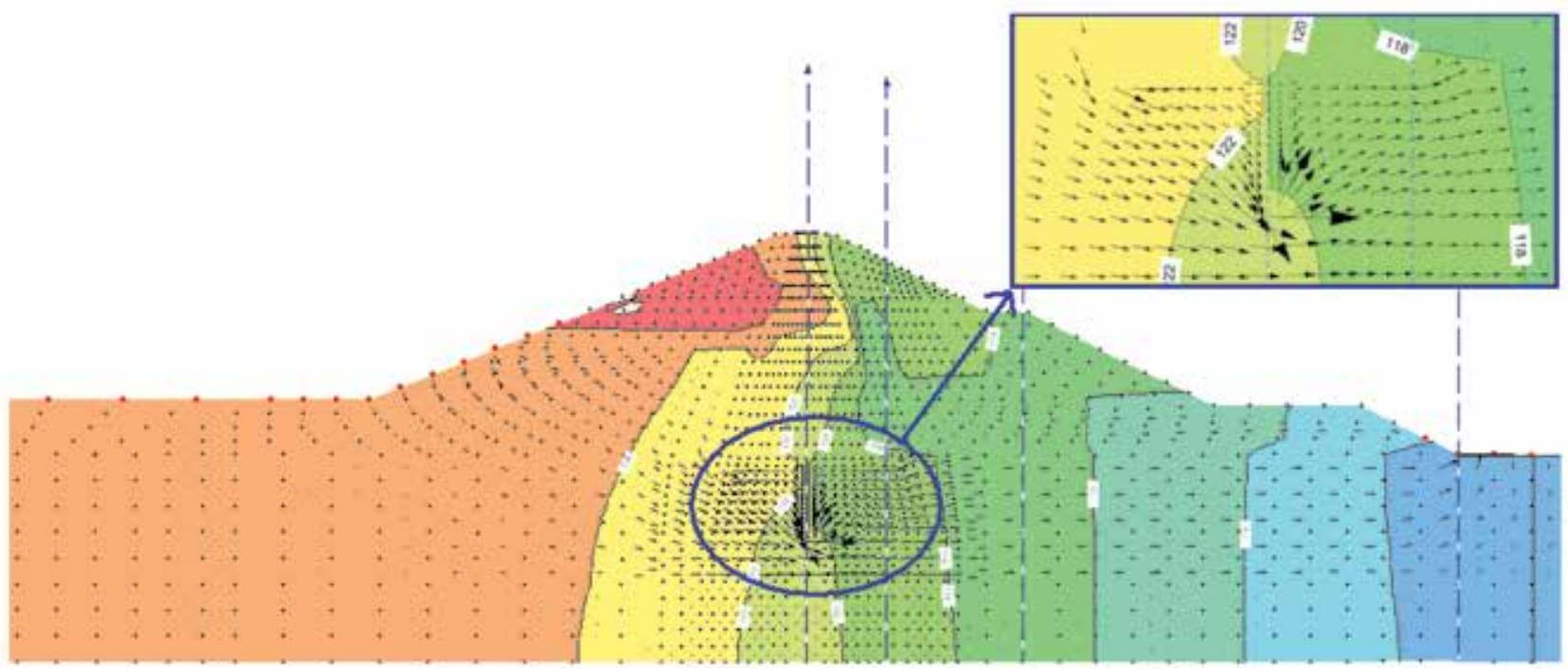

Figure 4. Numerical results of flow pattern in section 14 in Aug. 2011

are shown in Figure 4. In the downstream drain, the velocity varies from 0.3 to $0.5 \mathrm{~m} /$ day. By investigating velocity values in different zones, the minimum transport time of a water drop from upstream towards downstream would amount to about 540 days.

Since observation data show that the seepage flow is greater than the one predicted in design documents, different cases were considered for the unsteady seepage modelling. In each case, it was adopted that the hydraulic permeability of constructed shells and foundations exceeds the design data and that these data are as mentioned in Table 2, while other technical data remained the same as the design data. In case B1, the permeability value is the same as the design data reported in design documents. Seepage computation results for the variation of piezometric level in wall number 14 are drawn against measured values in Figure 5. Not much difference can be seen in computational results for several cases, and hence, no special conclusion can be derived.

Based on the above-mentioned notes, it may be argued that the difference between simulated piezometric levels in all 5 cases is not great. In other words, the variation of piezometric heads in seepage modeling seems to be insufficient for deciding between different seepage systems.

Table 2. Permeability values for shell and foundation in different cases

\begin{tabular}{|c|c|}
\hline Case & Permeability $[\mathrm{m} / \mathrm{s}]$ \\
\hline B1 & $2.3 \times 10^{-5}$ \\
\hline B2 & $4 \times 10^{-5}$ \\
\hline B3 & $6 \times 10^{-5}$ \\
\hline B4 & $8 \times 10^{-5}$ \\
\hline B5 & $2 \times 10^{-4}$ \\
\hline
\end{tabular}

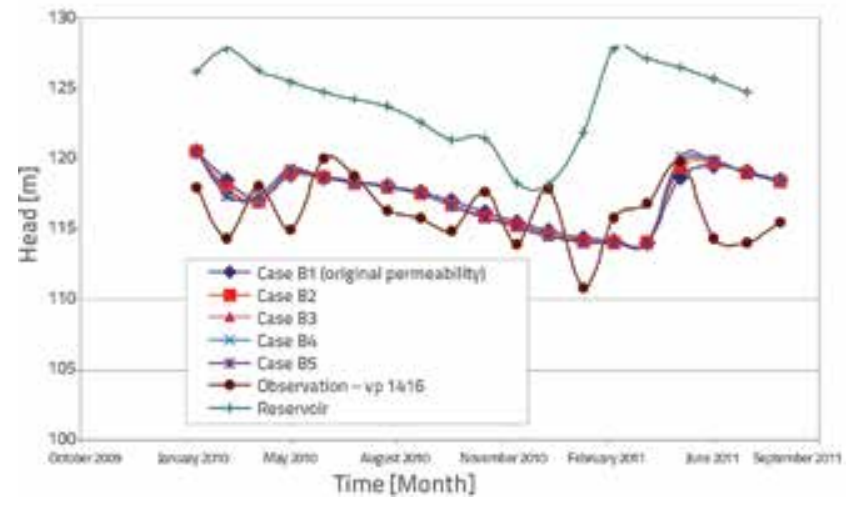

Figure 5. Time variation of piezometric head in Piezometer 1416, for all cases

\section{Temperature analysis}

The average velocity of seepage flow in the upstream shell amounts to about $0.3 \mathrm{~m} /$ day, while the velocity increases up to $1 \mathrm{~m} /$ day around the cutoff. As mentioned before, an average of minimum and maximum weather temperature during the last 30 years in dam region ranges between 19 and $35^{\circ} \mathrm{C}$. Since the maximum water depth in the dam reservoir is less than $10 \mathrm{~m}$, the water temperature in the dam reservoir is generally equal to the ambient temperature, and no vertical temperature gradient can be observed. Hence, the temperature variation shown in Figure 3 can be applied for all boundary elements at the upstream side of the dam. The seepage flow moving through the earthfill dam keeps these temporal variation values, and almost the same variation behavior can be observed in the elements located at the upstream side of the dam core. If there is a crack within the core, the water temperature variation generally corresponds to the water temperature variation in the reservoir. Based on the seepage analysis, temperature distribution in dam was simulated for one and a half year period by applying the mentioned boundary conditions. 

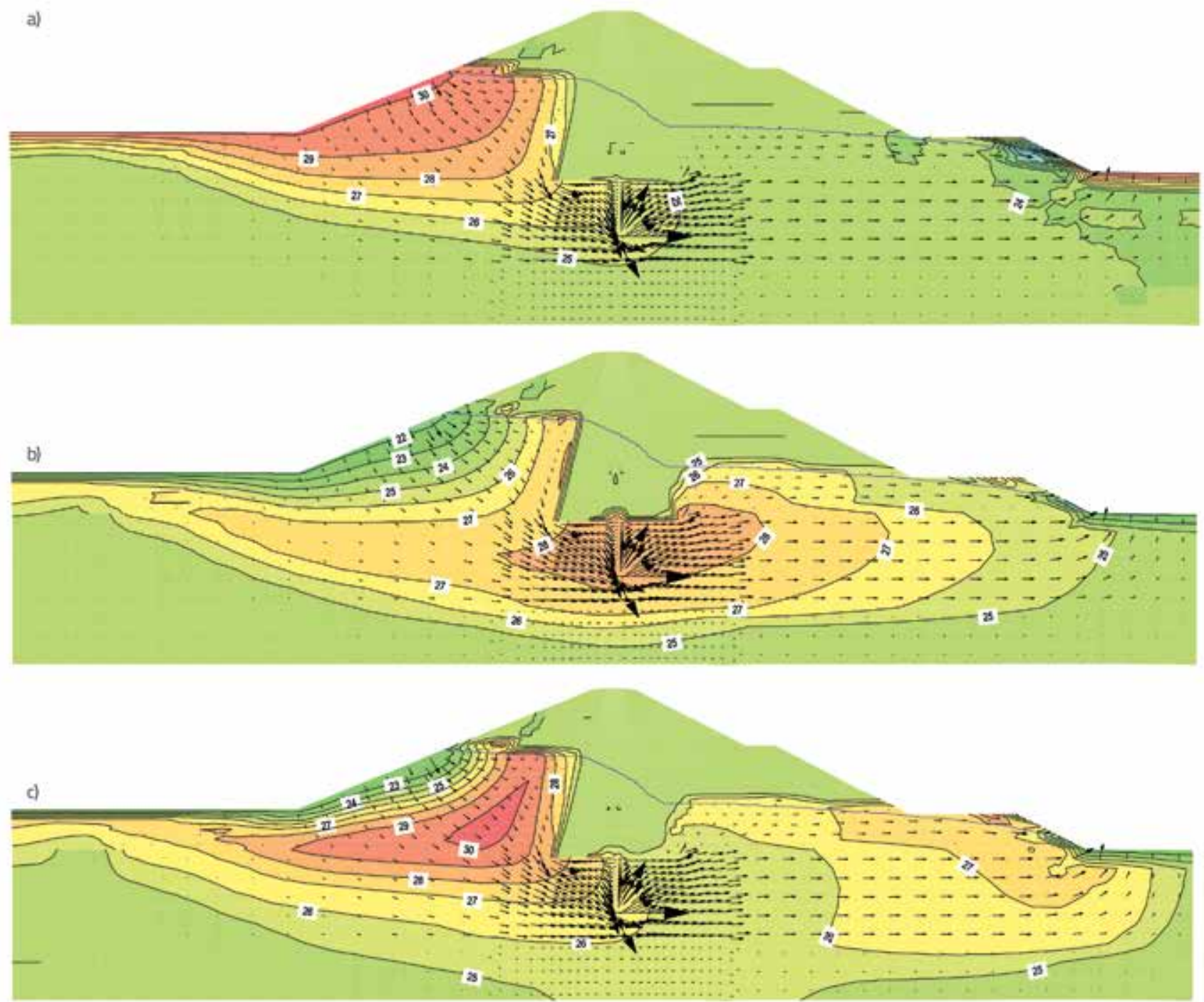

Figure 6. Simulated flow pattern and temperature counters in section 14: a) after 6 months in Aug. 2010; b) after 12 months in Feb. 2011 ; c) after 18 months in Aug. 2011

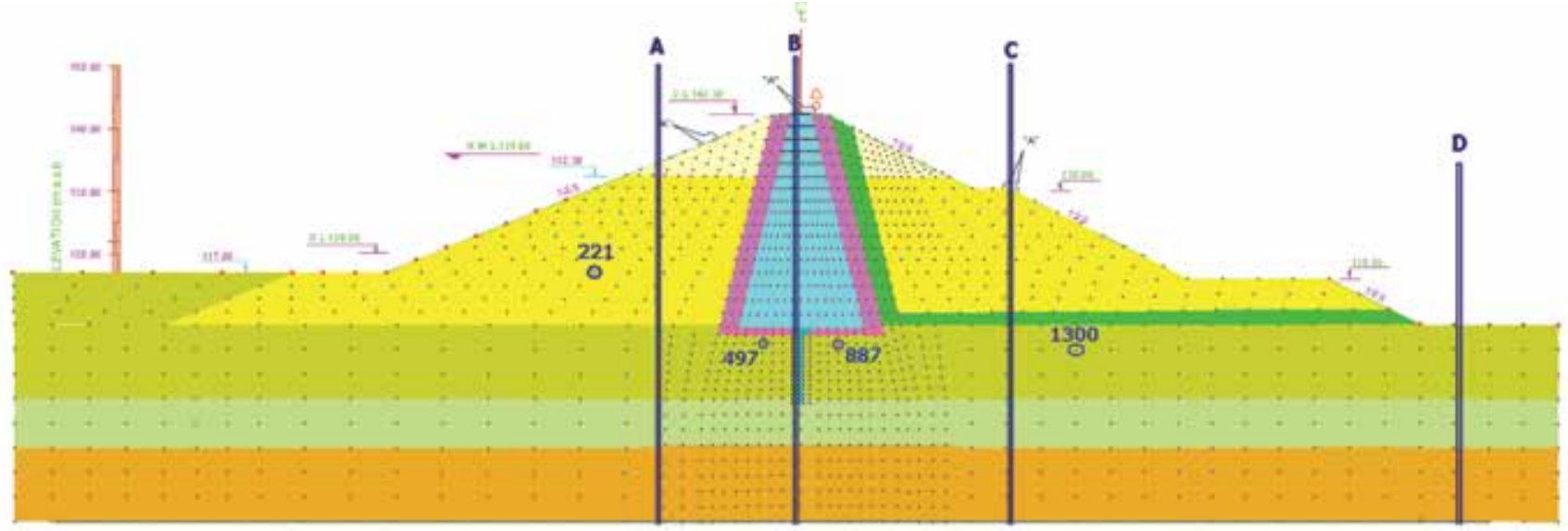

Figure 7. Location of relevant nodes (in which time variations of temperature are drawn) and location of discharge cross lines 
Temperature simulation results for 6,12 and 18 months are shown in Figure 6 . Differences between temperature values at the same locations at different times can clearly be seen at the upstream and downstream of the dam. Hence, temperature variations are very small at the downstream shell if there is no cracking in the dam core. However, greater temperature variations have been observed at the upstream shell. To evaluate temperature variation trends over time, four nodes in the dam body were considered, as shown in Figure 7. Temporal variations of temperature in these four nodes are shown in Figure 8.

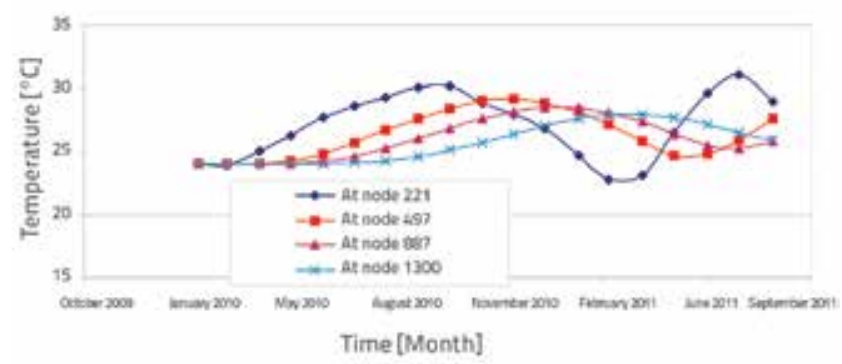

Figure 8. Temperature variation over time in different nodes: Node 221 in the upstream shell, Node 497 at the upstream of cutoff, Node 887 at the downstream of cutoff, Node 1300 in the middle of the drain (at the bottom)

\section{Discussion}

By comparing measured temperature values and numerical model results, it may be concluded that the hydraulic permeability of the dam shell exceeds by about three times the values presented in technical reports. Hence, it may be said that seepage in this cross section of dam seems to be mainly due to higher values of hydraulic permeability in the dam shell. Five described cases (B1 B5) were considered to evaluate the temperature behavior of the dam. The temperature variation of the elements at the downstream of the dam body can show the safety of the dam. The variation of temperature in node 1062 near the piezometer 1416 at the downstream of the core is shown in Figure 9. The variation of temperature in that node is drawn for all cases against measured data for Piezometer 1416 and the dam reservoir. It can clearly be seen that results for the case $\mathrm{B} 3$ seem to be closer to the measured when compared to other cases. Hence, it may be concluded that the average real hydraulic permeability factor of the dam body is almost the same as in case B3.

The evaluation of seepage discharge can also provide other results about the current situation at the dam. The discharges from the downstream shell were measured at 3 different times: Jan. 2011, Apr. 2011, and Jul. 2011, and the corresponding flow amounted to 3,5 and $5.5 \mathrm{~m}^{3} /$ day, respectively. Since the flow is considered as unsteady and as temporal boundary conditions are applied, the seepage discharge in different sections is not equal. The output discharge, passing across the line $\mathrm{D}$, can be verified through comparison with measured data, as mentioned above.

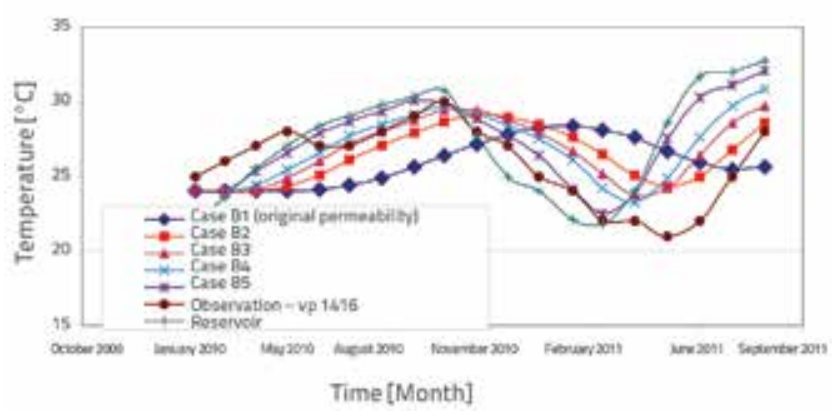

Figure 9. Time variation of temperature in Node 1062 and Piezometer 1416 for all cases

Four different vertical lines are considered in the dam section number 14, as shown in Figure 7. Line $A$ is located in the upstream shell, line $B$ in the dam core, line $C$ in the downstream shell, and line $D$ to the downstream of the dam after the toe. Discharges passing through these lines can be calculated and drawn for a time interval. These variations are drawn in Figure 10 for cases B1, B3 and B5. Differences between the discharge from line $C$ and line $D$ are equal to the discharge coming from the downstream shell of the dam.
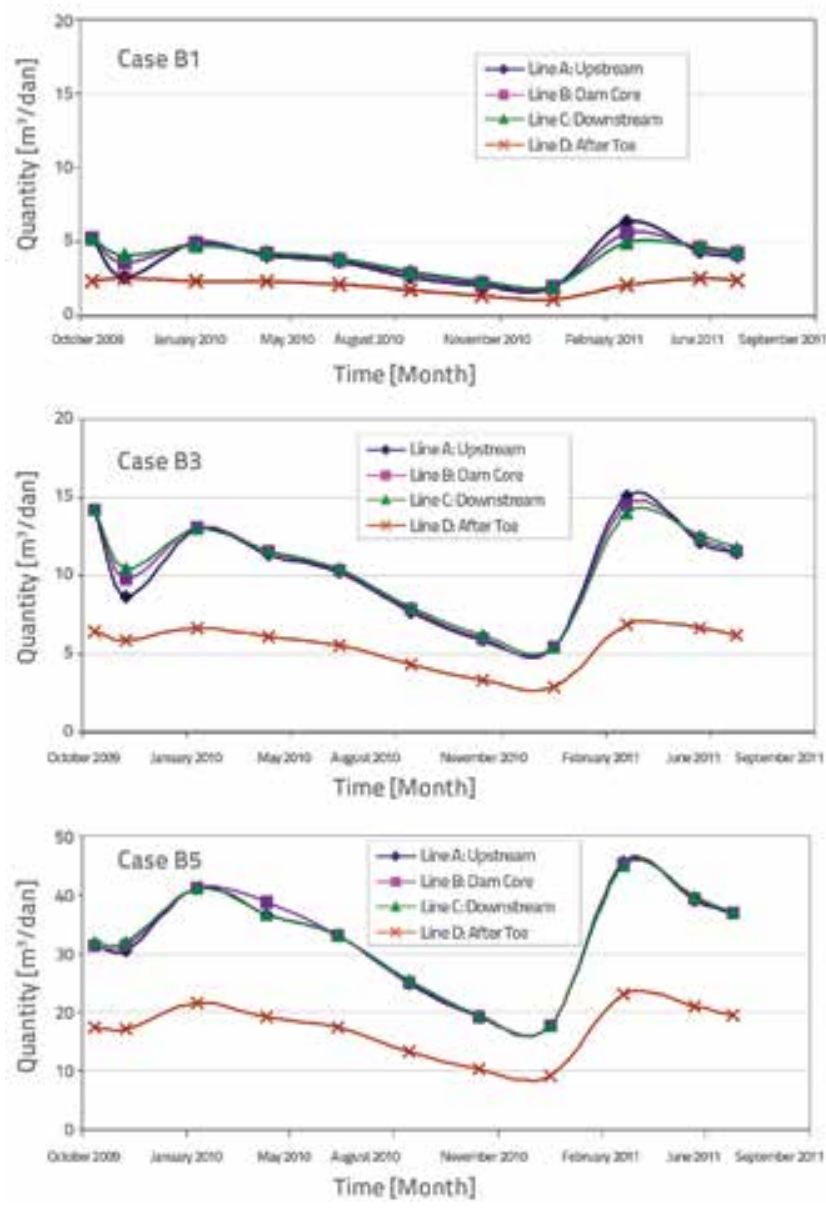

Figure 10. Time variation of discharges passing cross lines $A, B, C$ and D (Figure 7) for cases B1, B3 and B5 
Discharge difference between lines $C$ and $D$ can be obtained from Figure 10 for all cases from B1 to B5. For the case B3, the mentioned discharge difference for Jan. 2011 is $2.6 \mathrm{~m}^{3} /$ day, for Apr. 2011 it is $4.8 \mathrm{~m}^{3} /$ day and for Jul. 2011 it amounts to $5.7 \mathrm{~m}^{3} /$ day. It was established that the measured discharge from the downstream shell of the dam is somewhere between the discharges calculated for the case B3 and case B4, but is closer to the case $B 3$ results. Hence, from the seepage point of view, it can also be concluded that the case B3 is the most similar to the constructed dam.

\section{Conclusions}

A newly constructed earthfill dam named Shamil is studied in this paper to find seepage effect variation on piezometric head and temperature field within dam body during the study period of 1.5 years. A finite element model with triangular and quadrilateral elements is applied to simulate seepage flow and consequently temperature variation. The seepage and temperature are modelled by applying unsteady boundary conditions.

Similar to back analysis schemes, different cases were considered for numerical modeling of flow and temperature to find real conditions of constructed dam. In the first stage, the comparison between the measured piezometric head and seepage model results did not lead to any notable conclusions. In the next stage, the comparison of observed temperature values and thermal model results has revealed some differences between results in several cases. These differences were helpful in finding real constructed conditions. It was established that the hydraulic permeability coefficient of the dam shell exceeds by about 3 times the corresponding value specified in design documents. It can be concluded based on the back analysis of the earthfill dam seepage that the temperature variation inspection seems to be more efficient than the investigation of the piezometric head variation.

\section{REFERENCES}

[1] ICOLD: Dam Failures Statistical Analysis, Bulletin 99, 73P, 1995.

[2] Johansson, S.: Seepage Monitoring in Embankment Dams, Doctoral Thesis, Royal Institute of Technology, Stockholm, Sweden, 1997.

[3] Kappelmeyer, O.: The Use of Near Surface Temperature Measurements for Discovering Anomalies due to Causes at Depths. Geophysical Prospecting, Vol. 3, pp. 239-258, 1957.

[4] Merkler, G.P., Blinde, A., Armbruster, H., Doscher, H.D.: Field Investigations for The Assessment of Permeability and Identification of Leakage in Dams and Dam Foundations, 15th Congress of International Commission on Large Dams (ICOLD 1985), Q58, R7, Lausanne, Switzerland, 24-28 June 1985.

[5] Johansson, S.: Localization and Quantification of Water Leakage in Ageing Embankment Dams by Regular Temperature Measurements, Proc. ICOLD 17th Congress, Q65, R54, Vienna, Austria, 1991
[6] Cunat, P., Beck, Y.L., Fry, J.J., Courivaud, J.R., Fabre J.P., Faure, Y.H.: Surveillance of dyke ageing. Proc. of the 2nd International conference on Long Term Behaviour of Dams, Graz, Austria, 1213 October 2009

[7] Conrad, M., Aufleger, M., Malkawi, A.I.H.: An Advanced Temperature Monitoring System at Mujib and Wala Dam, In: Proc. of the Int. Conf. on Roller Compacted Concrete Dam Construction in Middle East 2002, Irbid, Jordan, 07.-10.04.2002. Eds. Malkawi, A. I. H., Aufleger, M., Strobl, Th., Irbid, J.: Jordan University of Science and Technology, 2002, 319 - 330, 2002.

[8] Johansson, S., Dahlin, T.: Seepage Monitoring in Hollby Embankment Dam by Continuous Resistivity Measurements, in Procs. 8th Congress of the International Ass. Of Eng. Geology and the Environment (ed. D. Moore and O. Hungr), Vancouver, Canada, 21-25 September 1998, pp. 95-102.

[9] Moshanir Co.: Shamil Dam Technical Report, 2007. 